\title{
PEMETAAN KARAKTERISTIK PERMUKIMAN KUMUH PESISIR UNTUK PENGELOLAAN BENCANA DI MAKASSAR
}

\author{
Naidah Naing ${ }^{1}$ \\ ${ }^{1}$ Jurusan Arsitektur, Universitas Muslim Indonesia
}

\begin{abstract}
Abstrak
Makassar merupakan salah satu kota yang sebagian wilayahnya merupakan kawasan permukiman pesisir. Namun perubahan iklim yang terjadi terus-menerus dilingkungan permukiman di pesisir, terkadang menyebabkan bencana banjir (ROB), angin kencang dan gelombang arus deras, yang setiap saat mengancam rumah-rumah berada dikawasan pemukiman pesisir. Hal ini akan mempengaruhi keberlanjutan ekonomi dan keberlanjutan kehidupan di kawasan tersebut. Tujuan penelitian ini adalah untuk mengidentifikasi karakteristik permukiman pesisir untuk pengelolaan bencana di kawasan pesisir Kota Makassar, agar kehidupan dapat terus berlangsung. Secara umum penelitian bersifat deskriptif-evaluatif dengan menggunakan dua pendekatan yaitu pendekatan Behaviour Approach dan Architectural Appproach (Neer, 1999). Pendekatan pertama berkaitan dengan dengan kajian proses memukimi oleh penduduk, "survival strategy" yang dimiliki oleh penduduk yang dimanifestasikan dalam kondisi sosio-ekonominya. Pendekatan yang kedua berkaitan dengan kajian perumahan dan pola permukiman. Kedua pendekatan tersebut dioperasionalisasikan dengan comparative perspective, yaitu dengan membandingkan eksistensi permukiman yang disaring melalui mekanisme penentuan tipologi karakteristik permukiman. Hasil penelitian menunjukkan bahwa karakteristik permukiman kumuh cenderung mengelompok dan menyebar tidak teratur. Masyarakat menempatkan rumahnya secara alami langsung berhadapan dengan pantai, dengan mata pencaharian sebahagian nelayan sehingga rumah-rumah diletakkan menyebar tak teratur. Hal ini akan ditata kembali berdasarkan struktur ruang kawasan yang telah ada. Kemudian akan dikembangkan sesuai dengan standar penataan kawasan tepi air/ waterfront city yang berlaku. Dari karakteristik ini akan menghasilkan model pengelolaan bencana di kawasan pesisir Makassar.
\end{abstract}

Kata kunci: karakteristik permukiman pesisir, pengelolaan bencana

\begin{abstract}
Makassar is one of the cities that most of the region is an area of coastal settlements. But climate change is happening constantly in the coastal settlements, causing floods, high winds and waves of the flood, which at any moment threatens homes located area of coastal settlements. This will affect the economic viability and sustainability of life in the region. The purpose of this study was to identify the characteristics of coastal settlements for disaster management in the coastal area of the city of Makassar, so that life can continue. Generally, this research is descriptive-evaluative using two approaches, Behaviour and Architectural Approach Appproach(Neer,1999).The first approach deals with the study of the process of resettlement of residents, "survival strategy" that is owned by a resident that is manifested in the socio-economic conditions.The second approach deals with the study of the housing and settlement patterns. Both approaches operationalized by comparative perspective, by comparing the existence of the settlements were filtered through mechanisms for determining the characteristic typology of settlements. The results showed that the characteristics of slums tend to cluster and spread irregularly. Society naturally put his house directly opposite the beach, with the livelihoods of some fishermen, so the houses are put spread erratically. This will be reorganized based on the structure of the existing regional chamber. Then it will be developed in accordance with the standard arrangement of the waterfront district / waterfront city regulations. From these characteristics will produce a model of disaster management in the coastal area of Makassar.
\end{abstract}

Keywords: characteristics of coastal settlements, disaster management

\section{PENDAHULUAN}

Indonesia merupakan salah satu negara kepulauan terbesar di dunia yang meliputi kurang lebih 17.508 pulau - pulau dan memiliki garis pantai sepanjang $81.000 \mathrm{~km}$. Sehingga sebagian besar wilayah di Indonesia merupakan kawasan pesisir. Saat ini, berbagai kawasan pesisir di beberapa kota di Indonesia mengalami kerusakan yang cukup parah yang diakibatkan oleh adanya fenomena alam yang secara geografis memiliki kekhasan tersendiri. Keadaan ini menyebabkan kawasan pesisir menjadi andalan sumber pendapatan masyarakat Indonesia. Secara umum, wilayah pesisir dapat didefenisikan sebagai wilayah pertemuan antara ekosistem darat, ekosistem laut dan ekosistem udara yang saling bertemu dalam suatu keseimbangan yang rentan. 
Kota Makassar merupakan salah satu kota pesisir yang ada di Indonesia yang memiliki garis pantai sepanjang $32 \mathrm{~km}$ yang mencakup 11 pulau - pulau kecil dengan luasan keseluruhan mencapai 122.370 ha atau sekitar 1,1\% dari luas wilayah daratannya. Fakta tersebut menjadikan Kota Makassar memiliki berbagai kawasan wisata pesisir. Kota Makassar merupakan salah satu kota yang sebagian wilayahnya merupakan kawasan permukiman pesisir.

Tujuan penelitian ini adalah untuk mengembangkan model penataan permukiman kumuh untuk pengelolaan bencana di kawasan pesisir Kota Makassar, agar kehidupan dapat terus berlangsung. Secara umum penelitian bersifat deskriptif-evaluatif dengan menggunakan dua pendekatan yaitu pendekatan Behaviour Approach dan Architectural Appproach. Pendekatan pertama berkaitan dengan dengan kajian proses memukimi oleh penduduk, "survival strategy" yang dimiliki oleh penduduk yang dimanifestasikan dalam kondisi sosio-ekonominya. Pendekatan yang kedua berkaitan dengan kajian perumahan dan pola permukiman. Kedua pendekatan tersebut dioperasionalisasikan dengan comparative perspective, yaitu dengan membandingkan eksistensi permukiman yang disaring melalui mekanisme penentuan tipologi karakteristik permukiman.

\section{ISI PENELITIAN}

\subsection{Metode Penelitian}

a. Pendekatan Penelitian

Secara umum penelitian bersifat deskriptifevaluatif dengan menggunakan dua pendekatan yaitu pendekatan Behaviour Approach dan Architectural Appproach (Neer, 1999). Pendekatan pertama berkaitan dengan dengan kajian proses memukimi oleh penduduk, "survival strategy" yang dimiliki oleh penduduk yang dimanifestasikan dalam kondisi sosio-ekonominya. Pendekatan yang kedua berkaitan dengan kajian perumahan dan pola permukiman. Kedua pendekatan tersebut dioperasionalisasikan dengan comparative perspective, yaitu dengan membandingkan eksistensi permukiman yang disaring melalui mekanisme penentuan tipologi karakteristik permukiman.

b. Lokasi Penelitian

Lokasi penelitian ini berada di kawasan pesisir kategori permukiman kumuh. Wilayah studi mencakup 3 (tiga) kecamatan yaitu Kecamatan Ujung Tanah Kelurahan Cambaya, Kecamatan Tallo Kelurahan Tallo dan Kecamatan Biringkanaya Kelurahan Untia.

c. Metode Pengumpulan Data

Pengumpulan data dapat dilihat dari berbagai setting. Pada penelitian ini bila dilihat dari settingnya, data dikumpulkan pada setting alamiah di tiap kecamatan yang masuk dalam wilayah studi permukiman kumuh pesisir, sedangkan bila dilihat dari sumber datanya, maka dapat digunakan sumber data primer dan sumber data sekunder. Selanjutnya cara atau teknik pengumpulan data dalam penelitian ini adalah observasi berperan serta (participan observation), wawancara mendalam (indepth interview), studi dokumentasi melalui perekaman gambar melalui foto atau film dan juga merekonstruksikan skala sosial.

d. Metode Analisis Data

Analisis data dalam penelitian kualitatif dilakukan sejak sebelum memasuki lapangan, selama di lapangan dan setelah selesai di lapangan. Namun demikian, analisis data lebih difokuskan selama proses di lapangan bersamaan dengan pengumpulan data dalam periode tertentu. Pada saat wawancara, peneliti sudah melakukan analisis terhadap jawaban yang diwawancarai setelah dianalisis terasa belum memuaskan, maka peneliti akan melanjutkan pertanyaan lagi, sampai tahap tertentu, diperoleh data yang dianggap kredibel.

Analisis data dalam penelitian ini dilakukan dengan menggunakan teknik analisis spasial dan analisis statistik deskriptif (tabel frekuensi maupun tabel silang). Dalam studi ini, digunakan unit analisis permukiman kumuh pesisir.

Hasil pemetaan karakterisitik permukiman dan kondisi sosio-ekonomi diwujudkan dalam bentuk peta karakteristik permukiman dan kondisi sosioekonomi penduduk daerah penelitian yang selanjutnya dipetakan dalam bentuk tipologi permukiman kumuh pesisir. Disamping itu juga dilakukan pemetaan kondisi fisik lingkungan daerah penelitian selanjutnya dianalisis secara statistik (analisis frekuensi dan tabel silang). Dari hasil analisis ini dapat diturunkan output penelitian berupa pemetaan kawasan permukiman yang rawan bahaya bencana gelombang pasang, angin kencang, banjir akibat air pasang dan abrasi pantai.

\subsection{Hasil dan Pembahasan}

\section{a. Karakteristik Permukiman Kumuh Pesisir}

Terbentuknya suatu lingkungan binaan dalam hal ini adalah permukiman, merupakan proses pewadahan fungsional yang dilandasi oleh pola aktivitas manusia serta adanya pengaruh setting (rona lingkungan) baik yang bersifat fisik maupun non fisik (sosial budaya) yang secara langsung mempengaruhi pola kegiatan dan proses pewadahannya. Rona lingkungan akan saling berpengaruh dengan lingkungan fisik yang terbentuk oleh kondisi lokasi, kelompok masyarakat dengan sosial budayanya. Hubungan antar aspek budaya (culture) dan lingkungan binaan (environment) dalam kaitannya dengan perubahan berjalan secara komprehensif dari berbagai aspek kehidupan sosial budaya masyarakat.

\section{Kelurahan Cambaya Kecamatan Ujung Tanah}

Lokasi penelitian Pertama ini merupakan salah satu kawasan pesisir yang ada di Kota Makassar, terletak di Kecamatan Ujung Tanah Kelurahan Cambaya. 
Dalam Kelurahan Cambaya ini terdapat 5 RW dan 22 RT Jumlah penduduk kelurahan Cambaya 6.079 jiwa penduduk, yang terdiri dari laki-laki sebanyak 3.581 jiwa dan perempuan 2.498 jiwa. Dari 6.079 jiwa jumlah penduduk terdiri dari 1.255 kepala keluarga. Dengan kepadatan penduduk 12.015/ $\mathrm{Km}^{2}$.

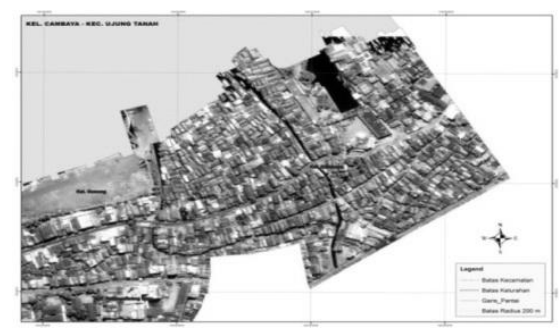

Gambar 1 : Peta Udara Kelurahan Cambaya

Berdasarkan data diatas Pola permukiman penduduk di Kelurahan Cambaya umumnya linier dan berbanjar, tidak teratur dengan tingkat kepadatan bangunan tinggi. Pertumbuhan penduduk yang tidak terkendali mengakibatkan Kelurahan Cambaya menjadi kelurahan yang padat dan kumuh. Tingkat kepadatan penduduk pada Kelurahan Cambaya terdapat pada RW 1 yang mencapai $65 \%$ dan RW 3 dan RW 4 juga memiliki tingkat kepadatan yang sangat tinggi yaitu $80 \%$ yang mengakibatkan kurangnya ruang terbuka hijau pada ketiga RW tersebut dan juga membuat sirkulasi jalan sangat sempit Hampir seluruh bagian kelurahan telah terbangun oleh rumah penduduk, sehingga hanya $\pm 10 \%$ dari permukaan daratan adalah ruang terbuka.

Dilihat dari jumlah kepala keluarga atau jumlah penduduk, banyak kebutuhan lahan yang harus terpenuhui.Akan tetapi penggunaan lahan yang di gunakan sebagian besar warga tesebut merupakan lahan pemerintah.Dalam hal ini status tanah yang mereka gunakan merupakan hak pakai (liar). Tercatat dari hasil responden $50 \%$ yang menggunakan lahan sebagai Hak pakai (liar), 33\% yang berstatus sebagai hak milik dan $17 \%$ berstatus sebagai hak guna. Akibat dari tingginya tingkat kepemilikan tanah yang berstatus liar dapat menurunkan kualitas permukiman.

Dengan kondisi tersebut maka antisipasi terhadap angin kencang terantisipasi. Akan tetapi sangat rawan jika terjadi kebakaran. Rumah yang berada di pinggiran laut memiliki jarak sangat dekat. Apabila di perhatikan antara jarak pantai dan permukiman tersebut sepertinya masyarakat di Kelurahan Cambaya tidak mempertahankan sempadan pantai. Tingginya tingkat kepadatan bangunan menyebabkan vegetasi jarang sekali kita dapatkan.

\section{Kelurahan Untia Kecamatan Biringkanaya}

Kelurahan Untia merupakan salah satu kelurahan yang terletak di Kecamatan Biringkanaya. Luas wilayah Kelurahan Untia $2.89 \mathrm{~km}$, terdiri dari $5 \mathrm{RW}$ dengan luas keseluruhan 2,89 $\mathrm{km}^{2}$. Kawasan ini termasuk dalam kawasan pengembangan pemukiman penduduk, industri dan pariwisata. Area kelurahan Untia meliputi jalan Sallodong dan jalan Ir. Sutami. Adapun beberapa titik di kelurahan Untia yang hanya berupa jalan setapak dan lorong - lorong kecil. Untuk pencapaian, sebelah utara berbatasan dengan wilayah maros.

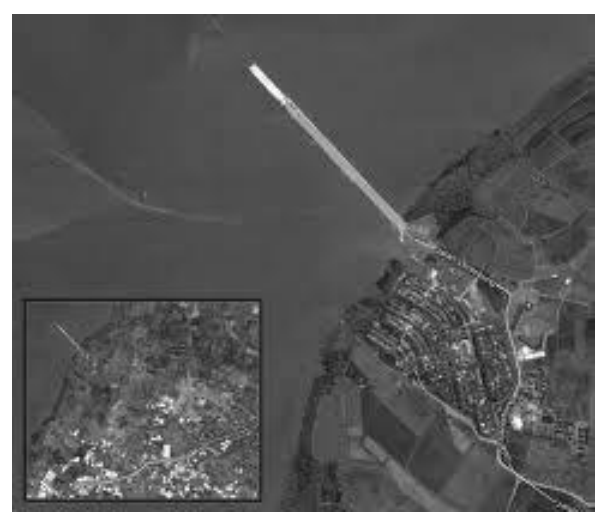

Gambar 2 : Peta Udara Kelurahan Untia

Jumlah keseluruhan penduduk di Kelurahan Untia adalah 2.060 dengan jumlah laki-laki 1.073 jiwa dan jumlah perempuan 987 jiwa. Dengan jumlah KK 421. Jumlah penduduk laki-laki terbanyak berada di RW 2 sebanyak 576 jiwa. Sedangkan jumlah penduduk laki-laki paling sedikit berada pada RW 4. Sedangkan jumlah penduduk perempuan terbanyak berada pada RW 1 dengan jumlah penduduk 432 Jiwa. Dan jumlah perempuan paling sedikit berada pada RW 3.

Dari pengamatan di lokasi, pola permukiman penduduk di Kelurahan Untia umumnya linier mengikuti pola jaringan jalan teratur dengan tingkat kepadatan bangunan sedang. Penggunaan lahan didominasi oleh permukiman nelayan dan sisanya ruang terbuka. Pola rumah di Kelurahan Untia sama dengan yang ada pada kelurahan sebelumnya yakni sistem deret diantarai dengan jalan lingkungan dengan lebar jalan $\pm 1,5-2,5$ meter. Dengan kondisi tersebut maka antisipasi terhadap angin kencang sangat baik. Perletakan vegetasi juga dapat meredam angin kencang yang sering terjadi di Kelurahan Untia. Rumah yang berada di pinggiran laut memiliki jarak sangat jauh, hal ini dipengaruhi dengan perletakkan vegetasi. Apabila di perhatikan dengan jarak tersebut sepertinya masyarakat di Kelurahan Untia tetap mempertahankan sempadan pantai yakni \pm 20 meter.

\section{Kelurahan Tallo Kecamatan Tallo}

Lokasi penelitian yang ketiga ini merupakan salah satu kawasan pesisir yang ada di Kota Makassar, Kelurahan Tallo. Secara administratif terletak di Kecamatan Tallo, Kota Makassar. Jumlah penduduk sebanyak 8.017 jiwa yang terdiri dari laki - laki sebanyak 3.898 jiwa dan perempuan sebanyak 4.119 jiwa. Jumlah keluarga pra sejahtera di Kelurahan Tallo adalah sebanyak 1.043. 
Berdasarkan pengamatan di lapangan pola permukiman penduduk di Kelurahan Tallo umumnya linier dan menyebar mengikuti jaringan jalan tidak teratur dengan tingkat kepadatan bangunan sedang. Penggunaan lahan didominasi oleh permukiman kemudian industri pengolahan minyak dan sisanya ruang terbuka privat.

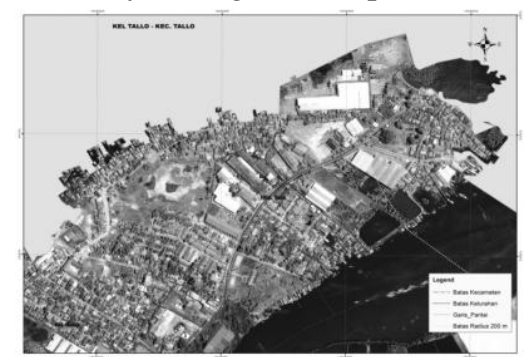

Gambar 3 : Peta Udara Kelurahan Tallo

Pola rumah di Kelurahan Tallo sama dengan yang ada pada kelurahan sebelumnya yakni sistem deret diantarai dengan jalan lingkungan dengan lebar jalan $\pm 1,2-2,5$ meter. Dengan kondisi tersebut musibah angin kencang masih dapat mengancam. Akan tetapi jika terjadi kebakaran masih dapat diatasi dengan cepat. Rumah yang berada di pinggiran laut memiliki jarak sangat dekat. Apabila di perhatikan antara jarak pantai dan permukiman tersebut sepertinya masyarakat di Kelurahan Tallo tidak mempertahankan sempadan pantai. Bahkan masih ada rumah yang bermukim diatas air.

\section{Kondisi Fisik Bangunan Kelurahan Cambaya kecamatan Ujung Tanah}

Hasil rekapitulasi quesioner sesuai dengan kondisi fisik bangunan masih terdapat bangunan sederhana dan semi permanen yang mencapai $27 \%$, permanen $37 \%$ panggung $27 \%$ dan non permanen $9 \%$.

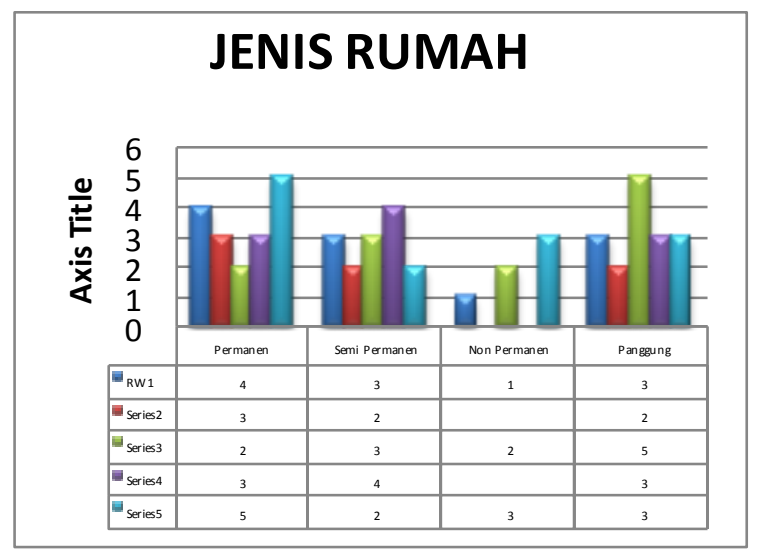

Gambar 4 : Pie Chat Jenis Bangunan Kelurahan Cambaya

Luas bangunan yang ditempati masyarakat disana beraneka ragam ada yang ukurannya $36 \mathrm{~m}^{2}$ dan ada juga mempunyai luas bangunan yang ukurannya $21 \mathrm{~m}^{2}$, didalam bangunan yang luas bangunannya sekitar $36 \mathrm{~m}^{2}$ dihuni 6-7 Orang didalamnya dan rata-rata dalam satu unit mempunyai 2 KK didalam setiap unitnya, dan yang mempunyai luas bangunan $21 \mathrm{~m}^{2}$ didalamnya dihuni 3-4 Orang didalamnya dan rata-rata didalamnya terdapat $1 \mathrm{KK}$.

Dari hasil rekapitulasi data di atas perlu satu langkah taktis untuk menangani masalah tersebut, yaitu memberikan pemahaman kepada warga tentang bagaimana menempati hunian dengan kapasitas sesuai dengan ukuran rumah yang mereka miliki, menjaga lingkungan agar tetap bersih dan sehat.Serta memberikan pemahaman tentang penggunaan bahan bangunan yang alamiah.

\section{Kondisi Fisik Bangunan Kelurahan Untia}

Kecamatan Biringkanaya

Kondisi Fisik Bangunan di Kelurahan Untia dipengaruhi oleh status kepemilikan tanah dimana masih banyak yang memiliki status hak guna ini dikarenakan rumah-rumah yang ada diwilayah studi merupakan rumah nelayan yang difasilitasi oleh pemerintah Kota Makassar. Hal ini dapat kita lihat dari gambar diagram berikut:

Hal ini dapat di lihat bahwa status tanah pada warga Kelurahan Untia rata - rata masih hak guna. Hal ini di karenakan warga Kelurahan Untia juga sebagian juga berasal dari daerah lain yang memanfaatkan rumah dari pemerintah yang kosong karena belum di tempati. Adapun warga Kelurahan Untia juga yang mencoba memanfaatkan rumah yang belum di tempati untuk tinggal karena sudah memiliki keluarga baru.

\section{STATUS TANAH}

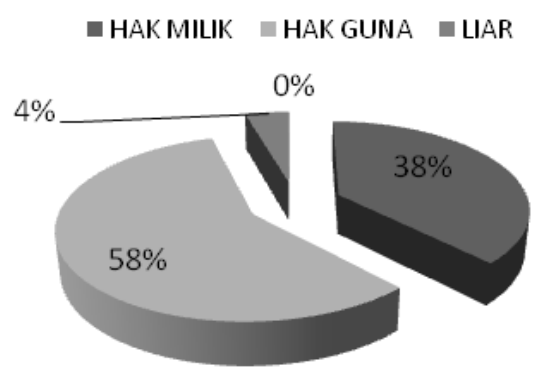

Gambar 5 : Status Kepemilikan Tanah

Status kepemilikan tanah juga dapat mempengaruhi pemeliharahaan dan pengembangan rumah-rumah warga di Kelurahan Untia, dimana warga rata-rata sudah permanen dan semi permanen. Hal ini dapat kita lihat dari Gambar diagram berikut:

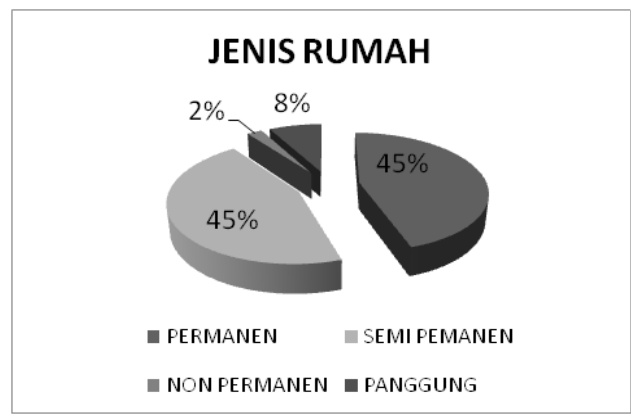

Gambar 6 : Jenis Rumah 


\section{Kondisi Fisik Bangunan Kelurahan Tallo Kecamatan Tallo}

Berdasarkan pengamatan di lapangan kondisi fisik bangunan di Kelurahan Tallo sangat beragam. Mulai dari rumah permanen dan semi-permanen. Ini terlihat jelas mulai dari dinding menggunakan material batu-bata dan di finishing keramik, dan lantainya juga telah menggunakan keramik. Tapi sebagian besar struktur rumah menggunakan kayu dan bahan atap dari seng.

Selain kondisi fisik bangunan, adapula kondisi bangunan rumah yang ada di Kelurahan Tallo yang bermukim diatas air. Umumnya mereka yang bermukim diatas air atau rumah terapung adalah mereka yang bermata pencaharian sebagai nelayan.

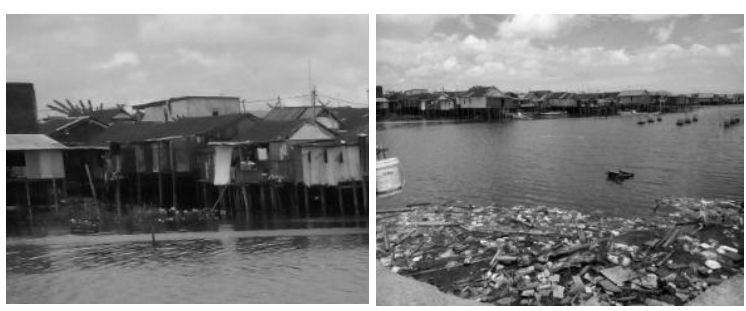

Gambar 7 : Rumah di Atas Air

\section{Bencana yang Sering Melanda Wilayah Kota Makassar}

Luas wilayah Kota Makassar sebesar 175,77 $\mathrm{km} 2$ pada ketinggian antara 0-25 m diatas permukaan laut, dengan suhu antara $20-32{ }^{\circ} \mathrm{C}$. Kota Makassar di lewati oleh 2 sungai utama yaitu Sungai Tallo dan Jeneberang. Sungai Jeneberang yang mengalir melintasi Kabupaten Gowa dan bermuara pada bagian Selatan kota dan Sungai Tallo yang bermuara di bagian Utara kota. Kedua sungai ini mempunyai kemiringan dasar sungai yang relatif sangat landai $( \pm 1 / 10.000)$ di bagian hilir. Kecepatan alirannya lambat dengan laju sedimentasi yang cukup tinggi sehingga mempunyai kecenderungan membentuk meander dan perubahan alur.

Bencana yang sering melanda wilayah Kota Makassar antara lain banjir, angin puting beliung/angin kencang dan kebakaran pemukiman. Bencana yang dominan adalah banjir. Banjir dengan skala besar mulai terjadi sejak tahun 2004 dan awal tahun 2013 banjir kembali terjadi di Makassar yang melanda 21 kelurahan di 6 kecamatan dan menyebabkan 4.555 orang yang harus mengungsi. Kerugian yang ditimbulkan diperkirakan Rp. 11,69 M.

Berdasarkan data geologi dan pengamatan indikasi di lapangan, Pemerintah Kota Makassar dalam buku Rencana Induk Pengembangan Pariwisata Perkotaan (RIPP) Kota Makassar tahun 2010/2011, menguraikan bahwa wilayah Kota Makassar mempunyai potensi terhadap terjadi bencana alam seperti:

a. Banjir/genangan air

Banjir/genangan air disebabkan oleh volume air yang terlalu banyak akibat terjadinya musim hujan dan pasang naik air laut, dapat terjadi pada daerah Kecamatan Tallo, Panakkukang, Tamalate serta Manggala.

b. Instrusi air laut

Instrusi air laut disebabkan oleh penyusupan air laut kearah daratan melalui pori-pori batuan/tanah dimana pada skala besar dapat mengakibatkan terjadinya amblesan (turunnya permukaan tanah). Hal ini potensil terjadi pada daerah Kecamatan Tamalate, Makassar, Ujung Pandang, Ujung Tanah, Wajo, Tallo, dan Biringkanaya.

c. Abrasi/Erosi

Abrasi/erosi adalah proses pengikisan tanah/batuan oleh air, baik air laut (abrasi) maupun air sungai (erosi) yang menyebabkan terjadinya ketidakstabilan permukaan lereng/tebing (pantai/sungai). Hal ini dapat terjadi pada daerah aliran sungai (S. Jeneberang, S. Tallo, S. Bulurokeng) dan daerah pantai (Kecamatan Tamalate, Tallo, Makassar, Ujung Tanah, Biringkanaya, dan daerah Kepulauan).

d. Sedimentasi/Akrasi

Sedimentasi/Akrasi adalah proses penimbunan massa pasir atau lempung pada daerah sungai (sedimentasi) dan daerah pantai (akrasi). Hal ini potensil terjadi pada daerah Tanjung Bunga, Tanjung Alang, Tanjung Merdeka, Barongbong, daerah Pelabuhan Sukarno Hatta, Muara sungai Jeneberang, dan Muara Sungai Tallo serta daerah meander (kelokan sungai) dan daerah cekungan (rawa).

e. Retakan tanah

Retakan tanah yang dapat terjadi di wilayah Kota Makassar merupakan retakan yang relatif kecil (tetapi diperlukan perhatian serius) yaitu berkisar antara 1-3 cm. Hal tersebut disebabkan oleh adanya kandungan mineral lempung "minmirolonite" pada sebagian tanah penyusun Kota Makassar. Retakan tanah dapat terjadi pada daerah Kecamatan Biringkanaya, Panakkukang, Tallo, Tamalate, dan Ujung Tanah.

Berdasarkan observasi di lapangan, bencana yang telah melanda dan berindikasi akan terjadi pada permukiman yang berada pada wilayah studi dapat di kategorikan sebagai berikut :

1. Kelurahan Cambaya Kecamatan Ujung Tanah
a. Kebakaran pada Tahun 200
b. Intrusi Air Laut
c. Abrasi/Erosi dan,
d. Retakan Tanah

2. Kelurahan Untia Kecamatan Biringkanaya
a. Angin Puting Beliung
b. Intrusi Air Laut
c. Abrasi/Erosi dan,
d. Retakan Tanah

3. Kelurahan Tallo Kecamatan Tallo
a. Angin Puting Beliung
b. Intrusi Air Laut
c. Abrasi/Erosi dan 


\section{d. Retakan Tanah}

\section{Kondisi Fisik Lingkungan}

Kota Makassar merupakan kota pesisir yang keadaan wilayahnya datar dan hanya sebagian kecil dataran tinggi yang terdapat di Kecamatan Biringkanaya, sepanjang DAS Sungai Tallo, Kecamatan Tamalanrea, Manggala, Panakukang, Ujung Pandang, Wajo, dan Ujung Tanah. Secara keseluruhan ketinggian dari permukaan laut untuk wilayah ini berkisar antara 1-25 meter diatas permukaan laut dengan kemiringan tanah rata-rata 0 $5^{\circ}$ ke arah barat.

\section{Kondisi Infrastruktur Wilayah Studi Kelurahan Cambaya Kecamatan Ujung Tanah}

a. Sarana Peribadatan

Pada Kelurahan Cambaya terdapat sarana penujung dalam permukiman seperti sarana peribatan yakni masjid sebanyak 2 unit yaitu Masjid Nurul Imam yang terletak pada RW 2 dan Masjid Babussalam yang berada pada RW 4. Selain masjid terdapat 1 langgar mengaji.

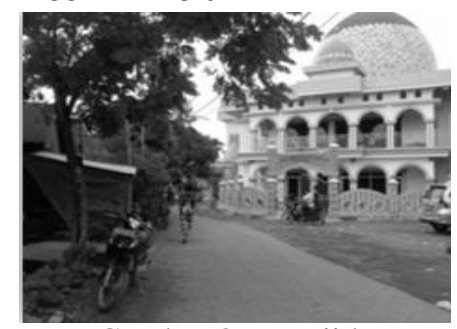

Gambar 8 : Masjid

b. Sarana Pendidikan dan Pemerintahan

Sarana pendidikan yang terdapat di kelurahan Cambaya terdiri dari 1 Sekolah Dasar (SD), 1 Sekolah Menengah Pertama (SMP), 1 Sekolah Menengah Atas (SMA) dan sama sekali tidak terdapat perguruan tinggi. Selain sarana pendidikan, terdapat 1 sarana pemerintahan yaitu Kantor Kelurahan Cambaya.

c. Sarana Kesehatan

Sarana kesehatan yang dimiliki kelurahan cambaya terdiri dari 5 posyandu yang terdapat di setiap RW dan tidak memiliki puskesmas maupun rumah sakit.

d. Sarana Fasilitas Umum dan Fasilitas Sosial

Adapun fasilitas komersial yakni pasar tidak ada di Kelurahan Cambaya sebagian ibu-ibu yang tinggal dirumah memanfaatkan waktunya untuk menjual sayuran dan sebagai usaha untuk menambah penghasilan.

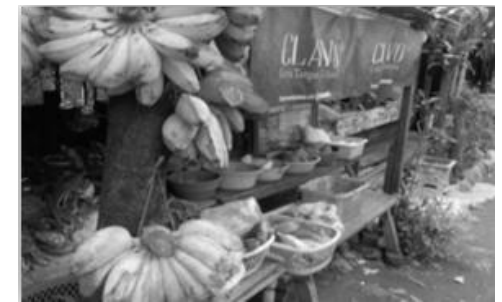

Gambar 9 : Pasar Rumahan e. Sarana Transportasi Air

Sarana transportasi darat yang dimiliki warga cambaya sebagian besar memiliki sepeda motor dan becak sedangkan transportasi air berupa perahu motor sebanyak 150 unit, kapal antar pulau 100 unit dan perahu / Jolloro 50 unit.

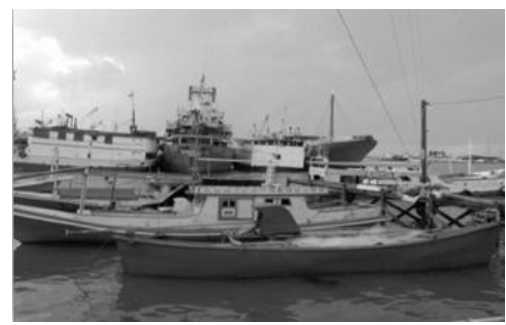

Gambar 10 : Transportasi Air

\section{f. Prasarana Drainase}

Kondisi drainase di Kelurahan Cambaya sudah terkontrol dengan baik. Terlihat dibeberapa RW yang menjaga kebersihan lingkungan drainase sehingga tidak terjadi penyumbatan atau tidak telihat penumpukan sampah. Akan tetapi, sebagian warga ada juga yang memang tidak peduli akan kebersihan drainasenya mereka membuang sampah pada drainase sehingga kondisi drainasenya menjadi kotor dan tersumbat.

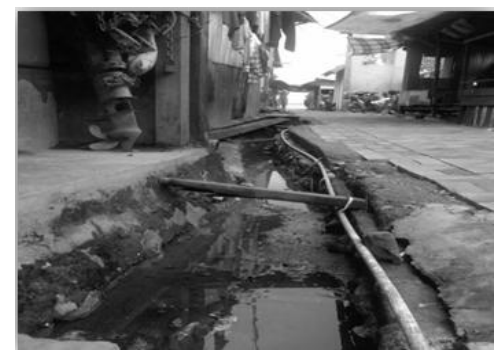

Gambar 11 : Kondisis Drainase

\section{g. Prasarana Jalan}

Untuk kondisi prasarana jalan yang ada di Kelurahan Cambaya sangat tidak kondusif. Hal ini terlihat pada ukuran gang-gang jalan yang sangat sempit untuk dilalui, dan gang tersebut tidak dapat dilalui oleh kendaraan bermotor ukuran gang tersebut mulai dari $0,5 \mathrm{~m}$ sampai dengan $1 \mathrm{~m}$ (lihat keterangan gambar) dengan kondisi jalan seperti yang ini cukup

h. Prasarana Air Bersih

Sumber air bersih di Kelurahan Cambaya masih kurang terdistribusi dengan baik, sehingga pada saat musim kemarau masyarakat memperolehnya dengan cara membeli air kepada warga yang memiliki sumber air bersih dengan harga Rp.12.000/jam. Mereka dapat memperoleh air bersih pada jam tertentu, yakni jam 01.00 malam sampai jam 04.00 pagi.

i. Prasarana Sampah

Dilihat dari kondisi lingkungan yang kurang baik, ini menandakan penanganan sampah. 

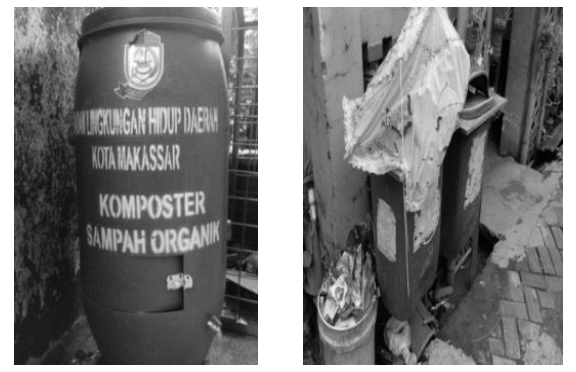

Gambar 12 : Kondisi Bak Sampah

\section{Kondisi Infrastruktur Wilayah Studi} Kelurahan Untia Kecamatan Biringkanaya

a. Jaringan Air Bersih

Jaringan air bersih dalam hal ini air dari PDAM telah melalui seluruh kawasan perumahan yang ada di Kecamatan Biringkanaya, hanya saja belum semua rumah menjadi pelanggan air bersih PDAM.

b. Sistem Persampahan

Sistem persampahan di Kecamatan Biringkanaya terdapat kontainer sebanyak 19 buah, TPS permanen sebanyak 28 buah dan TPS terbuka sebanyak 15 buah untuk lebih jelasnya dapat dilihat pada tabel berikut.

Tabel 1. Sistem Persampahan Kecamatan Biringkanaya 5 Tahun Terakhir (2010-2014)

\begin{tabular}{|c|c|c|c|}
\hline No. & $\begin{array}{c}\text { Tempat } \\
\text { pembuangan }\end{array}$ & $\begin{array}{c}\text { Jumlah } \\
\text { (unit) }\end{array}$ & $\begin{array}{c}\text { Persentase } \\
(\%)\end{array}$ \\
\hline 1. & Konteiner & 19 & 30,64 \\
\hline 2. & $\begin{array}{c}\text { TPS } \\
\text { Permanen }\end{array}$ & 28 & 45,16 \\
\hline 3. & $\begin{array}{c}\text { TPS } \\
\text { Terbuka }\end{array}$ & 15 & 24,19 \\
\hline \multicolumn{2}{|l}{ Jumlah } & 62 & 100,00 \\
\hline
\end{tabular}

\section{c. Jaringan Drainase}

Jaringan Drainase yang ada di Kecamatan Biringkanaya memiliki kondisi yang baik namun kadang fungsi dari drainase tersebut tidak sesuai lagi karena banyak terdapat sampah pada drainase tersebut, serta masih ada yang tidak memiliki jaringan drainase.

Tabel 2. Jaringan Drainase

\begin{tabular}{|c|c|c|c|}
\hline No & $\begin{array}{c}\text { Klasifikasi } \\
\text { Jaringan }\end{array}$ & $\begin{array}{c}\text { Panjang } \\
(\mathrm{km})\end{array}$ & Kondisi \\
\hline 1. & $\begin{array}{c}\text { Drainase } \\
\text { Primer }\end{array}$ & - & - \\
\hline 2. & $\begin{array}{c}\text { Drainase } \\
\text { Sekunder }\end{array}$ & 134 & Baik \\
\hline 3. & $\begin{array}{c}\text { Drainase } \\
\text { Tersier }\end{array}$ & $\mathbf{2 6 3}$ & Rusak \\
\hline
\end{tabular}

\section{Karakteristik Sosial Ekonomi dan Budaya} Kelurahan Untia Kecamatan Biringkanaya

a. Kondisi Sosial dan Ekonomi

Berdasarkan wawancara dengan 50 responden di lapangan ditemukan hasil persentase responden lakilaki $52 \%$ dan perempuan $48 \%$. Di setiap rumah penduduk terdapat jumlah KK yang berbeda-beda, dari data yang kami dapatkan rata-rata setiap rumah terdiri atas $1 \mathrm{KK}$, didominasi oleh lebih dari 5 orang. Hal ini ikut mempengaruhi konsidi sosial ekonomi diakibatkan pendapatan yang tidak seimbang dengan kebutuhan hidup.

Hal ini pun terkait juga dengan data yang kita dapat di lapangan mengenai tingkat pendidikan terakhir warga Kelurahan Untia.Dimana rata-rata pendidikan terakhir SD sebanyak 14\%, SMP $12 \%$, SMA 20\% dan Sarjana 4\%.

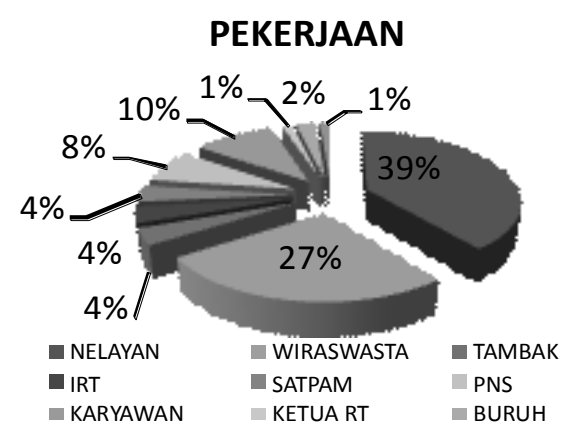

Gambar 13 : Jenis Pekerjaan

Warga pada Kelurahan Untia memiliki kondisi ekonomi yang rendah hal ini di sebabkan oleh pekerjaan warga yang belum mencapai kesejahteraan. Persentase rata-rata penghasilan warga dapat di lihat pada gambar berikut:

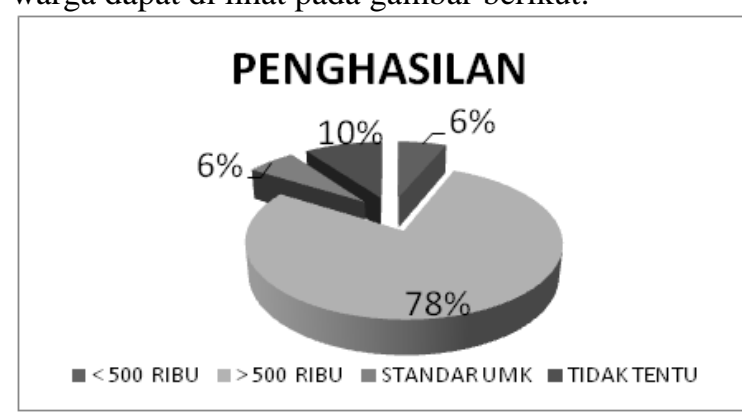

Gambar 14 : Tingkat Pengahasilan

Hal ini kita dapat menjelaskan bahwa warga di Kelurahan Untia masih memiliki penghasilan yang belum mencapai kesejahteraan hal ini pun di tambah dengan rata-rata keluarga di keluarahan tersebut memiliki lebih dari 4 orang anggota keluarga.

b. Kondisi Budaya

Warga pada Kelurahan Untia memiliki kondisi budaya yang baik. Setiap minggu terdapat kegiatan kegiatan positif yang terlaksanakan di pemukiman tersebut.banyak juga warga dari luar turut memberikan dukungan kegiatan dalam hal kegiatan baik, dari mahasiswa maupun pemerintah.

\section{Karakteristik Sosial Ekonomi dan Budaya Kelurahan Tallo Kecamatan Tallo}

a. Kondisi Sosial dan Ekonomi

Berdasarkan pengamatan dan observasi di lapangan, kondisi ekonomi (penghasilan), di 
Kelurahan Tallo 50\% masih berpenghasilan dibawah $500 \mathrm{ribu} /$ bulan, $50 \%$ yang berpenghasilan di atas $500 \mathrm{ribu} / \mathrm{bulan}$, dan yang berpenghasilan tidak menentu memiliki tingkat persentase sebanyak $0 \%$.

Sedangkan untuk pengeluaran, 12,5\% menghabiskan dana 100-300 ribu/bulan, $12,5 \%$ pengeluarannya $300-500$ ribu/bulan, $75 \%$ pengeluarannya di atas 500 ribu/bulan, dan yang pengeluarannya tidak menentu tingkat persentasenya adalah $0 \%$. Hal ini dapat dilihat dari gambar gambar dibawah ini.

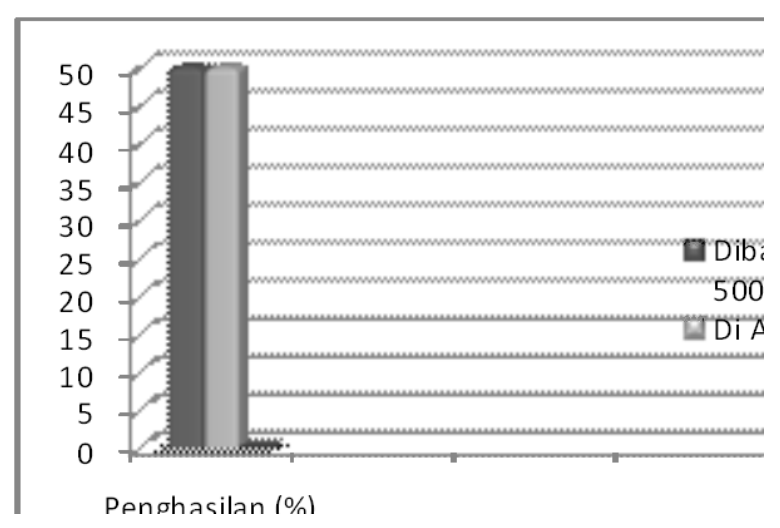

Gambar 15 : Grafik Penghasilan

\section{KESIMPULAN}

Dari hasil analisis diatas maka dapat disimpulkan sebagai berikut :

\section{A. Karakteristik Pemukiman Kumuh Pesisir \\ 1. Kelurahan Cambaya}

Tipologi Karakteristik permukiman kumuh kelurahan Cambaya terdiri dari :

- Pola permukiman linier, berbanjar dan tidak teratur dengan tingkat kepadatan bangunan tinggi.

- Pertumbuhan penduduk yang tidak terkendali mengakibatkan kelurahan cambaya menjadi kelurahan yang padat dan kumuh.

- Kurangnya ruang terbuka hijau pada kawasan pesisir ini dan juga sirkulasi jalan sangat sempit, hanya $\pm 10 \%$ dari permukaan daratan adalah ruang terbuka.

- Tidak terdapat jalur evakuasi bencana.

- Kondisi topografi kawasan yang cenderung landai tanpa cekungan, aksesibilats langsung ke pantai, menyebabkan kawasan ini rawan bencana angin kencang karena tidak adanya blocking.

2. Kelurahan Tallo

Berdasarkan hasil analisis dilapangan, maka Tipologi karakteristik permukiman di Kelurahan Tallo:

- Pola permukiman umumnya linier dan menyebar mengikuti jaringan jalan, tidak teratur dengan tingkat kepadatan bangunan sedang.
- Penggunaan lahan didominasi oleh permukiman kemudian Industri pengolahan minyak dan sisanya ruang terbuka privat.

- Pola rumah di Kelurahan Tallo adalah sistem deret diantarai dengan jalan lingkungan dengan lebar jalan $\pm 1,2-2,5$ meter.

- Kondisi topografi lingkungan permukiman agak landai sehingga sebagaian penduduk memilih bermukim di atas air dengan rumah panggung dan sebagian dipesisir pantai dengan jenis rumah panggung dan permanen.

- Tidak memiliki jalur evakuasi bencana.

3. Kelurahan Untia

Dari hasil analisis yang ada, tipologi karakteristik permukiman di Untia adalah :

- Pola permukiman di Kelurahan Untia umumnya linier mengikuti pola jaringan jalan, teratur dengan tingkat kepadatan bangunan sedang.

- Penggunaan lahan didominasi oleh permukiman nelayan dan sisanya ruang terbuka.

- Pola rumah di Kelurahan Untia adalah sistem deret diantarai dengan jalan lingkungan dengan lebar jalan $\pm 1,5-2,5$ meter.

- Kondisi topografi permukiman cenderung rata dan aksesibilitas tidak langsung ke pantai.

- Sudah memiliki jalur evakuasi secara tidak langsung.

B. Sistem Mitigasi Bencana yang sesuai dengan Tipologi Permukiman Pesisir

1. Kelurahan Cambaya

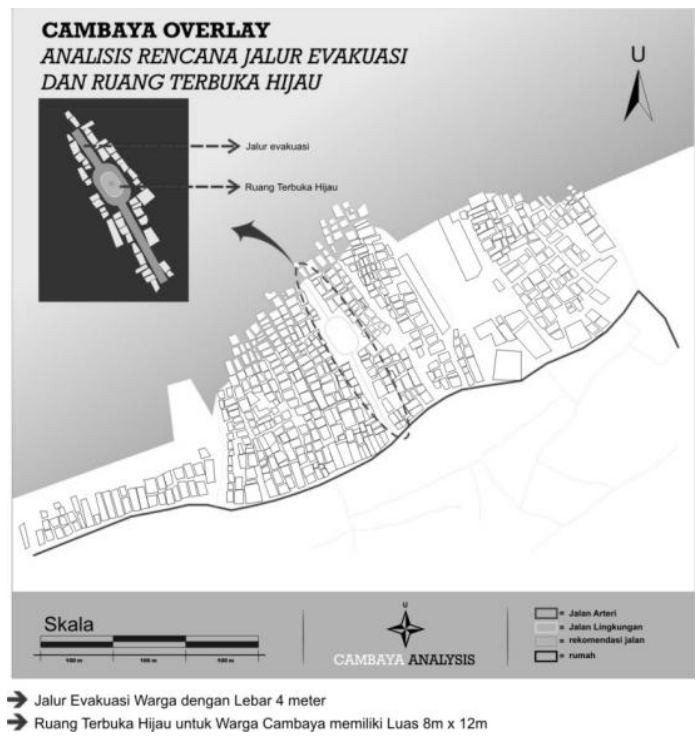

Berdasarkan observasi di lapangan, bencana yang telah melanda dan berindikasi akan terjadi pada permukiman yang berada pada wilayah Kelurahan Cambaya Kecamatan Ujung Tanah dapat di kategorikan sebagai berikut :

a. Kebakaran pada Tahun 2005

b. Intrusi Air Laut

c. Abrasi/Erosi dan,

d. Retakan Tanah

Dengan pola permukiman tersebut diatas maka perlu membuka akses dengan lebar 4 meter dan 
ruang terbuka hijau untuk membuat jalur evakuasi ketika terjadi bencana.

\section{Kelurahan Tallo}

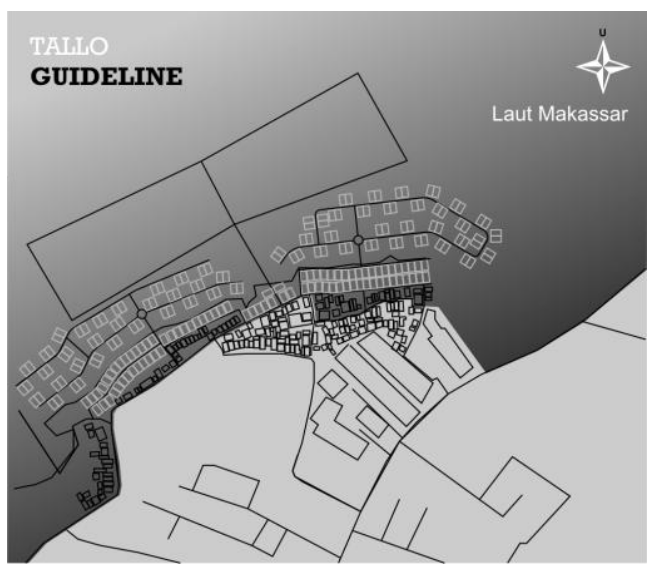

Berdasarkan observasi di lapangan, bencana yang telah melanda dan berindikasi akan terjadi pada permukiman yang berada pada wilayah Kelurahan Tallo Kecamatan Tallo dapat dikategorikan sebagai berikut :

a. Angin Puting Beliung

b. Intrusi Air Laut

c. Abrasi/Erosi dan,

d. Retakan Tanah

Dengan pola permukiman tersebut diatas maka perlu membuat penataan jaringan jalan pada permukiman terapung sehingga jalur evakuasi mudah diakses ketika terjadi bencana.

\section{Kelurahan Untia}

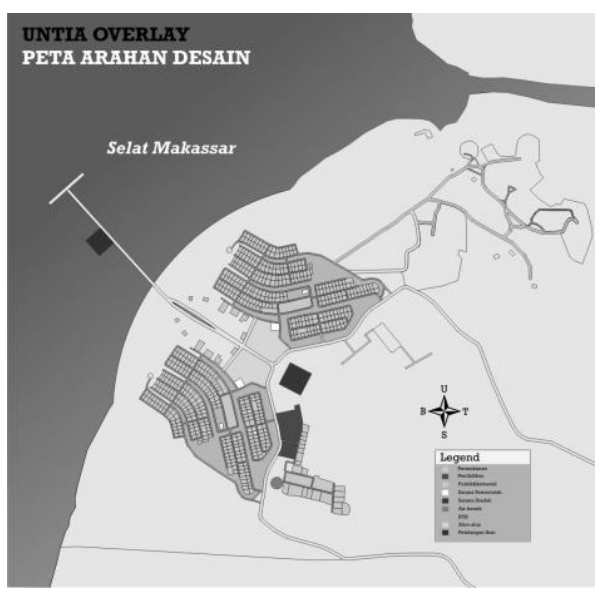

Berdasarkan Observasi dilapangan bencana yang telah melanda dan berindikasi akan terjadi pada permukiman yang berada pada wilayah Kelurahan Untia Kecamatan Biringkanaya dapat dikategorikan sebagai berikut

a. Angin Puting Beliung

b. Intrusi Air Laut

c. Abrasi/Erosi dan,

d. Retakan Tanah

Dengan pola permukiman tersebut diatas maka perlu membuat penataan kawasan pengembangannya agar tingkat sosial ekonomi masyarakat pulau yang akan direlokasi masuk ke wilayah ini semakin meningkat. Tentunya faktor mitigasi bencana menjadi konsep dalam pengembangan kawasan Untia Baru.

\section{DAFTAR PUSTAKA}

[1] Budi Prayitno, Mengembangkan Kawasan Tepian Air Berkarakter Lokal, D!A, edisi-6, hal \. 7$8,2000$.

[2]Djoko Sujarto, Penataan Ruang Dalam Pengembangan Wilayah pantai, 2005. p.1-17

[3]Faisal, Sanapiah (1990), Penelitian Kualitatif, Dasar dan Aplikasi, YA3, Malang.

[4]Indorf, Pinna, 2002, Konsep Ruang Pola Permukiman dalam Manusia dan Lingkungan, [5]Penerbit Grolier International, Jakarta.

Norberg C - Schulz (1985), The Concept of Dwelling, On The Way to Figure of Architecture, Rizolli International Publication Inc, New York.

[6]Rapoport, Amos (1969), House Form and Culture, Practice Hall Inc, Englewood Cliffs, N.J., New York.

[7]Sugiyono (2007), Metode Penelitian Kuantitatif Kualitatif dan $R$ \& D, Penerbit Alfabeta, Bandung. [8]Waterson, Roxana (2002), Rumah Tinggal dalam Manusia dan Lingkungan, Penerbit Grolier International, Jakarta. 